\title{
PEMBUATAN KITOSAN DARI KULIT UDANG SEBAGAI BAHAN PENGAWET TAHU
}

\author{
Shintawati Dyah P
}

\begin{abstract}
Abstrak
Maraknya penggunaan formalin dan borak pada bahan makanan dengan tujuan agar makanan lebih awet oleh pedagang yang tidak bertanggungjawab, membuat masyarakat menjadi resah. Bahan pangan yang sering ditambahkan formalin terutama untuk bahan makanan semi basah seperti tahu, mie, bakso, ikan, daging serta minyak/lemak. Produsen sering kali tidak tahu kalau penggunaan formalin sebagai bahan pengawet makanan tidaklah tepat karena bisa menimbulkan berbagai gangguan kesehatan bagi konsumen yang memakannya. Beberapa penelitian terhadap tikus dan anjing menunjukkan bahwa pemberian formalin dalam dosis tertentu pada jangka panjang bisa mengakibatkan kanker saluran cerna. Penelitian lainnya menyebutkan peningkatan risiko kanker faring (tenggorokan), sinus dan cavum nasal (hidung) pada pekerja tekstil akibat paparan formalin melalui hirupan (Holipah,2010). Untuk itu perlu dikembangkan bahan pengawet yang aman bagi tubuh dan lingkungan, salah satunya kitosan. Khitosan banyak digunakan di berbagai industri. Salah satu penerapan khitosan yang penting dan dibutuhkan dewasa ini adalah sebagai pengawet bahan makanan pengganti formalin. Kualitas khitosan sering dinyatakan dengan besarnya nilai derajad deasetilasi. Penelitian ini bertujuan untuk mengetahui seberapa efektifnya kitosan sebagai bahan pengawet tahu. Proses deproteinisasi dengan larutan $\mathrm{NaOH}(3.5 \% \mathrm{w} / \mathrm{v})$ selama 2 jam pada suhu $65^{\circ} \mathrm{C}$ dan proses demineralisasi dalam larutan $\mathrm{HCl}(1 \mathrm{~N})$ selama 30 menit pada suhu kamar. Proses deasetilasi dilakukan dengan memanaskan khitin dengan larutan $\mathrm{NaOH} 50 \%$, pada suhu $70^{\circ} \mathrm{C}$ selama 1 jam. Parameter respon adalah berapa lama mampu mengawetkan tahu. Hasil penelitian menunjukkan bahwa proses deasetilasi khitin menjadi khitosan adalah pada konsentrasi $\mathrm{NaOH}$ $50 \%$ dan suhu $70^{\circ} \mathrm{C}$ selama 1 jam yang memberikan derajat deasetilasi sebesar 71,2\%.. Total bakteri pada perendaman tahu selama 3 hari dalam larutan asam asetat ditambah chitosan, dalam larutan asam asetat saja 9,9.10, sehingga bisa disimpulkan bahwa khitosan dapat menghambat pertumbuhan bakteri.
\end{abstract}

Kata kunci: kulit udang, chitosan, derajat deasetilasi, pengawet tahu. 


\section{Pendahuluan}

Limbah kulit udang biasanya hanya dimanfaatkan untuk pakan ternak atau untuk industri makanan seperti pembuatan kerupuk udang. Limbah kulit udang mengandung bahan yang sangat berharga, yaitu khitin. Bahan ini apabila diproses lebih lanjut menghasilkan khitosan yang memiliki banyak manfaat dalam bidang industri. Khitosan merupakan bahan organik yang banyak digunakan di berbagai industri kimia. Salah satu penerapan khitosan yang penting dan dibutuhkan dewasa ini adalah sebagai pengawet bahan makanan pengganti formalin. Khitosan adalah bahan alami yang direkomendasikan untuk digunakan sebagai pengawet makanan karena tidak beracun dan aman bagi kesehatan. (Bautista-Banos, 2006).

Secara umum, cangkang kulit udang mengandung $27,6 \%$ mineral, $34,9 \%$ protein, 18,1\% khitin , dan komponen lain seperti zat terlarut, lemak dan protein tercerna sebesar $19.4 \%$ (Suhardi, 1992). Oleh karena itu untuk memperoleh (isolasi) khitin dari cangkang udang melibatkan proses-proses pemisahan mineral (demineralisasi) dan pemisahan protein (deproteinasi). Proses deproteinasi untuk menghilangkan kandungan protein dalam bahan baku yang pada mulanya protein ini berikatan kovalen dengan khitin, menggunakan larutan basa $\mathrm{NaOH}$ panas dalam waktu yang relatif lama.
Proses demineralisasi untuk menghilangkan garam-garam inorganik atau kandungan mineral yang ada pada khitin terutama $\mathrm{CaCO}_{3}$ menggunakan larutan asam $\mathrm{HCl}$ encer pada suhu kamar.

Dari khitin dapat dihasilkan khitosan dengan menghilangkan gugus asetil $\left(\mathrm{CH}_{3}-\right.$ $\mathrm{CO})$ sehingga molekul dapat larut dalam larutan asam, proses ini disebut sebagai deasetilasi, yaitu menghasilkan gugus amina bebas (-NH) agar khitosan memiliki karakteristik sebagai kation. Secara umum derajat deasetilasi untuk khitosan sekitar $60 \%$, dan sekitar 90 $100 \%$ untuk khitosan yang mengalami deasetilasi penuh. Harga ini tergantung dari bahan baku khitin yang digunakan dan proses yang dijalankan (Suhardi, 1992).

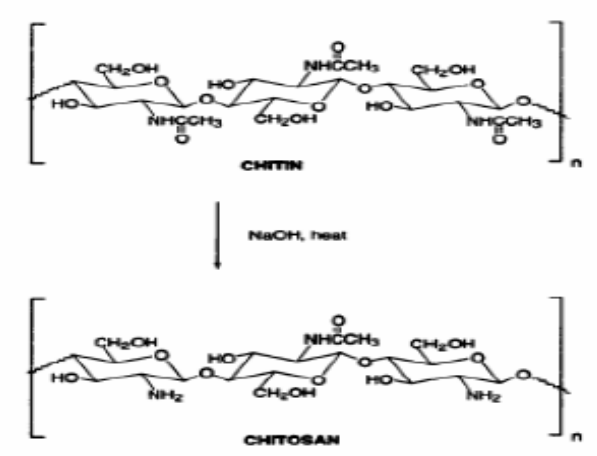

Gambar 1. Mekanisme Reaksi Pembentukan Chitosan dari Chitin

Derajat deasetilasi pada pembuatan khitosan bervariasi dengan jumlah larutan alkali yang digunakan, waktu reaksi, dan suhu reaksi. Biasanya kualitas produk chitosan dinyatakan dengan besarnya nilai derajad deasetilasi (Muzzarelli,1985 dan 
Austin,1988). Penelitian ini bertujuan untuk pengaruh kitosan terhadap aplikasinya sebagai pengawet tahu.

\section{Metode Penelitian}

Penelitian ini dilakukan melalui tiga tahap proses, yaitu tahap pembuatan khitin melalui proses deproteinasi dan demineralisasi, tahap deasetilasi, dan tahap aplikasi produk khitosan sebagai pengawet tahu.

\section{A Pembuatan Kitosan}

1. Proses Deproteinasi_dilakukan dengan menggunakan larutan 3,5 \% (w/v) $\mathrm{NaOH}$ pada suhu $65{ }^{\circ} \mathrm{C}$ selama 2 jam dengan pengadukan konstan (1200 rpm), rasio sampel larutan $\mathrm{NaOH}$ 1:4.

2. Proses demineralisasi dengan menggunakan larutan $\mathrm{HCl}(1 \mathrm{~N})$ pada suhu kamar selama 30 menit dengan pengadukan konstan (1200 rpm), rasio sampel : larutan $\mathrm{HCl} 1$ : 4.

3. Proses Deasetilasi dengan menggunakan rasio sampel : larutan $\mathrm{NaOH}=1: 25(\mathrm{gr} / \mathrm{ml})$, pengadukan konstan $1200 \mathrm{rpm}$ pada suhu 70 ( $^{\circ} \mathrm{C}$ ) dengan lama waktu 1 jam.

Ketiga tahap proses tersebut diakhiri dengan proses pencucian, penyaringan dan pengeringan. Hasil dari proses deasetilasi khitin untuk menghasilkan khitosan tersebut dianalisa derajat deasetilasinya (\% DD-nya) menggunakan analisa FTIR dengan menggunakan metode garis Moore dan Robert dengan menggunakan persamaan dibawah ini (Avadi dkk., 2004):

$\mathrm{DD}=\frac{1-A 3410}{A 1588} \times \frac{1}{1.33}$

Dengan :

Nilai

$\mathrm{A}($ Absorbansi $)=\log (\mathrm{Po} / \mathrm{P})$

$\mathrm{A}_{3410}=$ Absorbansi pada panjang gelombang $3410 \mathrm{~cm}^{-1}$ untuk serapan gugus hidroksi/amin (-OH, $\left.-\mathrm{NH}_{2}\right)$

$\mathrm{A}_{1588}=$ Absorbansi pada panjang gelombang $1588 \mathrm{~cm}^{-1}$ untuk serapan gugus asetamida ( $\left.\mathrm{CH}_{3} \mathrm{COONH}-\right)$

\section{B. Aplikasi Pengawetan Tahu}

Aplikasi perlakuan sampel tahu dengan proses perendaman tahu dengan konsentrasi berat kitosan $3 \mathrm{gr} / 1$ lt asam asetat $1 \%, 4 \mathrm{gr} / 1 \mathrm{lt}$ asam asetat $1 \%$, dan 5 $\mathrm{gr} / 1 \mathrm{lt}$ asam asetat $1 \%$,

Tahu dianalisa dengan : Uji Organoleptik dan penghitungan juml jumlah klon bakteri pada sampel tahu menggunakan metode TPC (total plate count).

\section{Hasil dan Pembahasan}

\section{Kitosan}

Karakteristik atau ciri dari kitosan dapat terlihat secara fisik maupun kimia yang hasilnya dapat dilihat pada Tabel 1.

Tabel 1. Perbandingan Kitosan yang dihasilkan dengan standar baku Kitosan

\begin{tabular}{|c|c|c|}
\hline $\begin{array}{c}\text { Standar } \\
\text { baku }\end{array}$ & Standar & Chitosan \\
Chitosan & yang \\
yang & & dihasilkan \\
\hline
\end{tabular}




\begin{tabular}{|c|c|c|}
\hline $\begin{array}{c}\text { berlaku } \\
\text { Spesifikasi }\end{array}$ & & \\
\hline Deasetilasi & $\begin{array}{l}\geq 70 \% \text { jenis } \\
\text { teknis dan } \\
>95 \% \text { jenis } \\
\text { pharmasikal }\end{array}$ & $71.2 \%$ \\
\hline Kadar abu & $\begin{array}{l}\text { Umumnya < } \\
1 \%\end{array}$ & $0,6 \%$ \\
\hline Kadar air & $2-10 \%$ & $4 \%$ \\
\hline Kelarutan & $\begin{array}{l}\text { Hanya pada } \\
\mathrm{pH} \leq 6\end{array}$ & $\begin{array}{l}\text { Pada } \mathrm{pH} \leq \\
6\end{array}$ \\
\hline $\begin{array}{l}\text { Kadar } \\
\text { nitrogen }\end{array}$ & $7-8,4 \%$ & $-10,2 \%$ \\
\hline Warna & $\begin{array}{l}\text { Putih sampai } \\
\text { kuning pucat }\end{array}$ & $\begin{array}{l}\text { Kuning } \\
\text { pucat }\end{array}$ \\
\hline $\begin{array}{l}\text { Ukuran } \\
\text { partikel }\end{array}$ & $\begin{array}{l}5 \\
\text { Mesh }\end{array}$ & - \\
\hline E. Coli & Negatif & Negatif \\
\hline Salmonella & Negatif & Negatif \\
\hline \multicolumn{3}{|c|}{$\begin{array}{l}\text { Sumber: Muzzarelli (1985) dan Austin } \\
\text { (1988) }\end{array}$} \\
\hline
\end{tabular}

Dari tabel 1 terlihat bahwa kecuali kadar nitrogen, produk khitosan yang dihasilkan telah memenuhi standar yang berlaku. Namun dari hasil analisa mikroba menunjukkan bahwa khitosan dengan kandungan nitrogen yang melebihi standart mutu masih bagus untuk digunakan sebagai bahan pengawet tahu.

Analisis kadar abu dapat digunakan untuk mengetahui mutu produk, antara lain tingkat kemurnian produk (Andarwulan dkk., 2008). Hal ini menunjukkan bahwa proses demineralisasi pada saat pembuatan kitosan telah berjalan dengan baik, sehingga tidak banyak mineral-mineral yang tersisa. Ciri fisik, kitosan yang dibuat dalam penelitian ini juga berupa serpihan bubuk. Secara keseluruhan, kitosan yang dibuat pada penelitian ini telah sesuai dengan mutu kitosan pada umumnya.

\section{Uji Organoleptik}

Uji organoleptik meliputi bau, tekstur dan warna dari tahu tanpa perlakuan dan tahu dengan perendaman konsentrasi kitosan. Hasil uji organoleptik dapat dilihat pada Tabel 2

Tabel 2. Uji organoleptik

\begin{tabular}{|c|c|c|c|}
\hline \multicolumn{4}{|c|}{ Hari ke 1} \\
\hline Sampel & $\mathrm{Bau}$ & Warna & Tekstur \\
\hline $\begin{array}{l}\text { Tahu tanpa } \\
\text { perlakuan }\end{array}$ & $\begin{array}{l}\text { Tahu } \\
\text { segar }\end{array}$ & $\begin{array}{l}\text { Putih } \\
\text { bersih }\end{array}$ & Kenyal \\
\hline $\begin{array}{l}\text { Tahu + } \\
\text { Kitosan } 3 \\
\%\end{array}$ & $\begin{array}{l}\text { Tahu } \\
\text { segar }\end{array}$ & $\begin{array}{l}\text { Putih } \\
\text { bersih }\end{array}$ & Kenyal \\
\hline $\begin{array}{l}\text { Tahu + } \\
\text { Kitosan } 4 \\
\%\end{array}$ & $\begin{array}{l}\text { Tahu } \\
\text { segar }\end{array}$ & $\begin{array}{l}\text { Putih } \\
\text { bersih }\end{array}$ & Kenyal \\
\hline $\begin{array}{l}\text { Tahu + } \\
\text { Kitosan } 5 \\
\%\end{array}$ & $\begin{array}{c}\text { Tahu } \\
\text { segar }\end{array}$ & $\begin{array}{l}\text { Putih } \\
\text { bersih }\end{array}$ & Kenyal \\
\hline $\begin{array}{l}\text { Tahu + } \\
\text { Asam } \\
\text { asetat } 1 \%\end{array}$ & $\begin{array}{l}\text { Tahu } \\
\text { segar }\end{array}$ & $\begin{array}{l}\text { Putih } \\
\text { bersih }\end{array}$ & Kenyal \\
\hline \multicolumn{4}{|c|}{ Hari ke 2} \\
\hline $\begin{array}{l}\text { Tahu tanpa } \\
\text { perlakuan }\end{array}$ & Asam & $\begin{array}{l}\text { Putih } \\
\text { kusam }\end{array}$ & $\begin{array}{l}\text { Kurang } \\
\text { kenyal }\end{array}$ \\
\hline $\begin{array}{l}\text { Tahu + } \\
\text { Kitosan } 3 \\
\%\end{array}$ & $\begin{array}{l}\text { Tahu } \\
\text { segar }\end{array}$ & $\begin{array}{l}\text { Putih } \\
\text { bersih }\end{array}$ & kenyal \\
\hline Tahu + & $\begin{array}{l}\text { Tahu } \\
\text { segar }\end{array}$ & Putih & kenyal \\
\hline
\end{tabular}




\begin{tabular}{|l|c|c|c|}
\hline $\begin{array}{l}\text { Kitosan 4 } \\
\%\end{array}$ & & bersih & \\
\hline $\begin{array}{l}\text { Tahu + } \\
\text { Kitosan 5 }\end{array}$ & $\begin{array}{c}\text { Tahu } \\
\text { segar }\end{array}$ & $\begin{array}{l}\text { Putih } \\
\text { bersih }\end{array}$ & kenyal \\
$\%$ & & & \\
\hline $\begin{array}{l}\text { Tahu + } \\
\text { Asam }\end{array}$ & Asam & $\begin{array}{l}\text { Putih } \\
\text { bersih }\end{array}$ & kenyal \\
asetat 1\% & & & \\
\hline
\end{tabular}

Hari ke 3

\begin{tabular}{|l|c|c|c|}
\hline $\begin{array}{l}\text { Tahu tanpa } \\
\text { perlakuan }\end{array}$ & $\begin{array}{c}\text { Sedikit } \\
\text { busuk }\end{array}$ & $\begin{array}{c}\text { Putih } \\
\text { sedikit } \\
\text { merah } \\
\text { bata }\end{array}$ & lembek \\
\hline $\begin{array}{l}\text { Tahu + } \\
\text { Kitosan 3 } \\
\text { gr }\end{array}$ & $\begin{array}{c}\text { Sedikit } \\
\text { asam }\end{array}$ & $\begin{array}{c}\text { Putih } \\
\text { bersih }\end{array}$ & Kenyal \\
\hline $\begin{array}{l}\text { Tahu + } \\
\text { Kitosan 4 } \\
\text { gr }\end{array}$ & $\begin{array}{c}\text { Tahu } \\
\text { kurang }\end{array}$ & $\begin{array}{c}\text { Putih } \\
\text { bersih }\end{array}$ & Kenyal \\
\hline $\begin{array}{l}\text { Tahu + } \\
\text { Kitosan 5 } \\
\text { gr }\end{array}$ & $\begin{array}{c}\text { Tahu } \\
\text { segar }\end{array}$ & $\begin{array}{c}\text { Putih } \\
\text { bersih }\end{array}$ & Kenyal \\
\hline $\begin{array}{l}\text { Tahu + } \\
\text { Asam }\end{array}$ & Asam & Putih & Kurang \\
asetat 1\% & & kusam & kenyal \\
\hline
\end{tabular}

Selama penyimpanan, tingkat aroma tahu dengan perendaman konsentrasi kitosan tampak tidak begitu berbeda, tetapi terdapat kecenderungan penurunan nilai bau. Hal itu mungkin disebabkan oleh perubahan bau yang semakin asam dari hari ke hari. Meskipun terjadi penurunan nilai bau, tahu dengan perendaman 5 gr masih cukup baik hingga penyimpanan hari ketiga.

Tekstur tahu tanpa perlakuan pada hari ketiga sudah melembek, sedangkan dengan perlakuan masih kenyal. Tekstur tahu dengan perlakuan kitosan 3 gr pada hari ke 3 sudah berkurang kekenyalannya. Selama masa penyimpanan, tekstur tahu dengan perendaman konsentrasi kitosan memiliki kecenderungan penurunan nilai kesukaan dari hari ke hari. Ini disebabkan oleh tekstur tahu yang semakin lembek sebagai akibat dari aktivitas mikrobia yang semakin meningkat.

Begitu juga dengan perubahan warna yang terjadi, tahu tanpa perlakuan pada hari ketiga sudah mengalami perubahan warna. Warna yang masih putih bersih pada tahu dengan perlakuan kitosan 5 gr.

3. Uji Mikroba

Tabel 3. Uji mikroba

\begin{tabular}{|l|c|c|c|}
\hline $\begin{array}{c}\text { Sampe } \\
1\end{array}$ & $\begin{array}{c}\text { Total } \\
\text { Bakteri } \\
\text { (Perenda } \\
\text { man 1 } \\
\text { hari) } \\
\text { (sel/gr) }\end{array}$ & $\begin{array}{c}\text { Total } \\
\text { bakteri } \\
\text { (Perenda } \\
\text { man 2 } \\
\text { hari) } \\
\text { (sel/gr) }\end{array}$ & $\begin{array}{c}\text { Total } \\
\text { bakteri } \\
\text { (Perenda } \\
\text { man 3 } \\
\text { hari) } \\
\text { (sel/gr) }\end{array}$ \\
\hline $\begin{array}{l}\text { Tahu }+ \\
\text { Kitosa } \\
\text { n 5 gr }\end{array}$ & $7,3 \times 10^{2}$ & $\begin{array}{c}1,37 \times \\
10^{3}\end{array}$ & $6,8 \times 10^{3}$ \\
\hline $\begin{array}{l}\text { Tahu }+ \\
\text { Kitosa } \\
\text { n } 4 \text { gr }\end{array}$ & $2,28 \times$ & $1,32 \times$ & $8,4 \times 10^{3}$ \\
\hline $\begin{array}{l}\text { Tahu }+ \\
\text { Kitosa } \\
\text { n 3 gr }\end{array}$ & $2,45 \times$ & $1,40 \times$ & $9,9 \times 10^{4}$ \\
\hline Tahu + & $4,2 \times 10^{2}$ & $7,4 \times 10^{5}$ & $9,9 \times 10^{5}$ \\
\hline
\end{tabular}




\begin{tabular}{|l|l|l|l|}
\hline $\begin{array}{l}\text { Asam } \\
\text { asetat } \\
1 \%\end{array}$ & & & \\
\hline $\begin{array}{l}\text { Tahu } \\
\text { tanpa } \\
\text { perlak } \\
\text { uan }\end{array}$ & $8,7 \times 10^{5}$ & $2,4 \times 10^{7}$ & $8,6 \times 10^{8}$ \\
\hline
\end{tabular}

Dari tabel 3 terlihat bahwa sampel tahu yang direndam dalam larutan asam asetat ditambah khitosan mengandung bakteri yang lebih sedikit $\left(6,8.10^{3}\right.$ sel/gram) dibanding dengan tahu yang hanya direndam dalam larutan asam asetat $\left(9,9.10^{5}\right)$ dan tahu tanpa perlakuan lebih banyak lagi jumlah bakterinya $\left(8,6 \times 10^{8}\right)$ Dilihat dari jumlah bakteri yang terhitung melalui metode TPC memperlihatkan bahwa semua sampel berada dibawah $10^{6}$ jumlah total bakteri yang menunjukan aman untuk dikonsumsi untuk produk serealia dan olahannya yang diperbolehkan oleh FAO.

\section{Kesimpulan}

1. Kondisi proses deasetilasi khitin menjadi khitosan adalah pada konsentrasi $\mathrm{NaOH} 50 \%$ dan suhu $70^{\circ} \mathrm{C}$ selama 1 jam yang memberikan derajat deasetilasi sebesar $71,2 \%$.

2. Total bakteri pada perendaman tahu selama 3 hari dalam larutan asam asetat ditambah chitosan $5 \%$ gradalah $6,8.10^{3}$, dalam larutan asam asetat saja $9,9.10^{5}$, dan tahu tanpa perlakuan 8,6.10 ${ }^{7}$. Kitosan 5 gr lebih efektif sebagai pengawet tahu.

\section{Daftar Pustaka}

Andarwulan, N., Kusnandar, F., dan Herawati, D. 2011. Analisis Pangan. Dian Rakyat. Jakarta.

Austin, P.R, Brine, C.J Castle, J.C., and Zikakos, J.P., (1988), “Chitin New Facets of Research” J. Food Sci, Vol.54.

Bautista-Banos, A.N., HernandezLauzardo, M.G., and Velazquez-del Valle, (2006), “Chitosan as a potential natural compound to control pre and postharverst diseases of horticultural commodities", Crop Protection, Elsevier Ltd, hal. 108 118.

Holipah, S. N., Wijayanti, E. dan Saputra, V. 2010. Aplikasi Kitosan Sebagai Pengawet Alami Dalam Meningkatkan Mutu Simpan Produk Pasca Panen. PKM Gagasan Tertulis. Institut Pertanian Bogor. Bogor.

Muzzarelly, (1985), "Studies on The Suitable of Chitinocistic Microorganism for Shrimp Waste Fermentation", Dissertation, University of Washington, New York.

Suhardi, (1992), “Khitin dan Khitosan", Pusat Antar Universitas Pangan dan Gizi UGM, Yogyakarta. 